\title{
Donald Trump: \\ a konzervatív defetizmus meghaladása
}

\author{
Donald Trump: Overcoming Conservative Defetism
}

Szilvay Gergely

https://doi.org/10.47707/Kulugyi_Szemle.2021.1.02

Összefoglaló: A tanulmány ismerteti Donald Trump elnöksége négy évének lehetséges örökségét és az amerikai jobboldalon mérvadó, illetve a Republikánus Párton belüli irányzatokat. Jelenleg háromféle módon itélik meg Trump személyét és az általa vezetett adminisztráció négy évét: ez a Demokrata Párt és a baloldal interpretációja, az ezredforduló Republikánus Pártjának irányzata, illetve az azzal szembeforduló, újkonzervatív felfogás. Az elemzés bemutatja a Republikánus Párton belül 2016 előtt folyt vitákat, majd a Trump-évekről a konzervatív szerzők által vont mérleget. Az örökség tekintetében rövid, közép- és hosszú távú hatásokat különböztet meg, ezek között említhető több bíró kinevezése. a politikai apátia megszüntetése és a viták felélénkítése, illetve azt. hogy alternatívákat teremtett az amerikai jobboldalon.

Kulcsszavak: USA, Donald Trump, Republikánus Párt, konzervativizmus

Abstract: The essay summarises the possible legacy of the presidency of Donald Trump and the camps and trends of the American Right and the Republican Party. Today there are three evaluations of the Trump years: the narrative of the Left and the Democratic Party: the narrative of the mainstream neoconservative Republican Party: and the narrative of the New Conservatism. The essay summarises the debates of the pre-2016 Republican Parly and the conservative analyses of the Trump presidency. The author differentiates short, middle and long-term effects. among them the appointment of judges, the ending of political apathy and instigating. debates, also creating alternative political possibilities on the American Right.

Keywords: USA, Donald Trump, Republican Parly, Conservalism 


\section{Bevezetés}

Vajon milyen politikai örökséget hagy maga után Donald Trump, az Amerikai Egyesült Államok 45. elnöke, aki 2017 és 2021 között szolgálta hazáját? Az alábbiakban a konzervatív publicisztika tükrében ke resek választ a kérdésre.

Donald Trump megosztó személyiség, ahogy a politikája is megosztó volt, így a politikai örökségéről is meglehetősen eltéró véle mények fogalmazódtak meg. Nem könnyű rövid idővel a leköszönése után tárgyilagosan elemezni az elnöksége négy évét, hiszen mesz sze vagyunk még attól, hogy „történelmi távlatoktól” szemlélhessüik azt, emellett sem közgazdasági, sem politológiai szakirodalom nem született még a Trump-korszakról olyan mennyiségben, hogy azokra támaszkodni lehessen.

Jelenleg három fő irányzatot különböztethetünk meg a volt elnök megítélése tekintetében. Az egyik az amerikai baloldal és a Demokrata Párt narratívája, amely szerint Trump 2016-os hatalomra kerülése a történelmi haladás kisiklása volt, mivel váratlanul megfosztotta Hillary Clintont attól a lehetőségtől, hogy az első afroamerikai után ő legyen az első női elnök. E felfogás szerint Trump végletesen megosztotta az amerikai társadalmat, személye és politikája nacionalista, radikálisan jobboldali, nőgyűlölő, rasszista, feketeellenes és a fehér felsőbbrendűség hirdetője. Úgy vélik, Donald Trump győzelme az alternatív jobboldalnak (alt-right) és a privilégiumaikat visszasíró, a veszteségeiket másokra projektáló fehér - Hillary Clinton kifejezé sével élve - „szánalmasoknak” köszönhető, akik nacionalisták, raszszisták, szexisták - és mindenekelőtt buták, akik nem értik a világ folyamatait (Tóth, 2016).

A második a Republikánus Párt 2016-ig domináns establishment jének az irányvonala, amelyet Donald Trump az elnökségért való indulásával és az elnökjelöltség 2016-os elnyerésével megkérdőjelezett, és amelyet szabadpiaci neoliberális jobboldaliságnak nevezhetnénk. Ehhez az irányvonalhoz kíván visszatérni a Republikánus Párton be lüli Lincoln Project kezdeményezés, amelyet néhány prominens Never 


\section{Külïgyi Szemle}

Trumper alapított, többnyire John McCain és Mitt Romney korábbi munkatársai, akik szerint a pártot lényegében életre hívó Abraham Lincoln egyesítette az országot (tekintve az ahhoz vezető háborút, ez az állítás megkérdőjelezhető), s most is erre van szükség. Ezért a szervezet tagjai a demokrata Joe Bidenre való szavazásra buzdították híveiket a 2020-as választások előtt. Önképük szerint a demokráciát és az alkotmányosságot védelmezik. Konkrétabb céljaik nemigen voltak, minthogy megakadályozzák Trump újraválasztását (The Lincoln Project, é. n.).

A harmadik irányzat azoké a jobboldaliaké, patrióta klasszikus liberálisoké és konzervatívoké, akik Donald Trump politikáját a korábbi republikánus politika kijavításaként vagy az afelé tett lépésként ér tékelik, akár kedvelik a személyét, akár nem. Szerintüik a Republikánus Párt túléléséhez éppen a Trump-féle felismerésekre volt szüikség, azaz - ha nem a párt, hanem a jobboldali meggyőződés szempontjából nézzük - egyszerűen a republikánusok eddig nem a megfelelő politikát folytatták.

\section{A Republikánus Párt irányzatai és a politikai spektrum}

A Republikánus Pártnak és Mitt Romney elnökjelöltnek a demokratákkal és Barack Obamával szembeni 2012-es veresége után a pártelit önvizsgálatot tartott, amelynek eredményeként Reince Priebus, a párt elnöke előterjesztette a jelentését, a párt új politikájának a főbb irányaira tett javaslatokkal egyetemben. A jelentés hivatalosan a Republican National Commiltee's Growth and Opportunity Project címet viselte, de a közbeszédben GOP Autopsy Reportként emlegették. A benne foglalt javaslat szerint:

- a pártnak a kisebbségek pártjává kell válnia, és céltudatosan nyitnia kell a hispánok felé, akik egyre nagyobb választói blokkot jelentenek;

- a bevándorlás kérdésében empatikusabb, az amnesztiához közelebb álló platformra kell helyezkedni; 
- a melegházasság ügyében kapitulálni kell, mert a szavazóbázis álláspontja változik, amit tudomásul kell venni;

- a szélsőjobbos hangokat ki kell szorítani, mert megbélyegzik és megválaszthatatlanná teszik az egész pártot; és végüil

- le kell rázni a „gazdag fehér férfiak pártja” bélyeget, mert a többség nem tud azonosulni ezzel a képpel (DocumentCloud, 2012; Stumpf, 2017).

Az álláspontok megoszlottak: egyesek szerint a javaslat a Republikánus Párt halálát, mások szerint a feltámadását hozta volna el.

Donald Trump viszont sutba dobta a Priebus-jelentést, sőt azzal teljesen ellentétes irányba tolta el a republikánus politikát, bebizonyítva, hogy pont nem a konzervatív politika további puhításával (hovatovább: feladásával), hanem annak a még határozottabb képviseleté vel lehet jobbról választást nyerni.

2016. szeptember 5-én egy politika- és médiatörténeti jelentősé günek bizonyult cikk jelent meg a Claremont Review of Books oldalán egy bizonyos Publius Decius Mus - mint késóbb kiderült, Michael Anton, az American Greatness szerzője - tollából, a címe „The Flight 93 Election" volt. Anton arra figyelmeztette benne a konzervatív es tablishment tagjait, hogy az addigi politikájuk és elképzeléseik semmire sem voltak jók; a feladatuk csupán annyi volt, hogy a washingtoni jólétért cserébe asszisztáltak a progresszió sikeréhez; és a szokásos republikánus recept már nem hat. Hozzátette: ha Hillary Clinton nyer, akkor a progresszív politikacsinálás új fokozatra fog kapcsolni. Ezért Trump hiába „rosszabb a tökéletlennél”, rá kell szavazni, mert ő nem olyan defetista és öncenzúrázó, mint a republikánus elit, és azt akarja, hogy „éljen az ország”. Anton szerint a 2016-os választás tétje az volt, hogy maradt-e bármiféle „virlü" és életösztön az amerikai társadalomban, vagy nem - ha igen, Trump nyer (Anton, 2016).

A cikk óriási vitát váltott ki, a szerzőt kiátkozta a jobboldal Trump ellenes része, akiknek egyre inkább a National Review lett az egyik

Niccolò Machiavelli nyomán használt fogalom, a jelentése: jellem, élni akarás (Mansfield, 1998). 


\section{Külïgyi Szemle}

vezető fóruma (Wilhelm, 2016), és természetesen a baloldal is: a The Allantic szerint az írás közlésével a Claremonı elárulta az alapítók és a konzervativizmus alapelveit valamiféle ,jobboldali autoritarianizmus" kedvéért (Friedersdorf, 2016).

Az amerikaiak azonban élni akartak: Trump győzött. 2020 decemberében pedig már Michael Anton cikkét egyesek „a Trump-korszak meghatározó esszéjeként" értékelték (Chait, 2020).

\section{A Trump-kormányzat mérlege konzervatív szemszögből}

Az amerikai demokraták és a nyugati baloldal - a saját vesztére - félreértelmezte a Trump-jelenséget, és lenézte az elnökjelölt szavazóit (Szilvay, 2016) - Trump viszont felemelte őket. Nem az alt-rightot, hanem azt a munkás- és alsó-középosztálybeli, Amerika középső részén élő fehér tömegeket, akikről már régóta megfeledkezett mindkét párt, így csak kis részük számított rendszeres szavazónak. Ez a réteg az, amely az előzô évtizedekben egzisztenciálisan nagyot zuhant, le szakadt Amerika többi részétől, és korábbi önmagához képest is hanyatlott. Trumpnak őket sikerült mobilizálnia és rávennie a voksolásra (Stumpf, 2017; Murray, 2012). A Donald Trumpra leadott szavazat egyben a hidegháborús konszenzus, a berlini fal leomlása utáni globális neoliberalizmus és a terjeszkedő, „birodalmi” külpolitika által meg határozott amerikai politika elleni protestszavazat is volt (Bacevich, 2020).

Szokássá vált Trumpot, az egykori demokrata szavazót, szélső jobboldalinak nevezni. Ez a megbélyegzés a politikai térképen az ér telmezési keretnek a folyamatos balra tolódásának az eredménye, és annak fokozódását szolgálja. Valójában Trump személyét akár olyan pragmatikus nemzeti liberálisnak is tarthatnánk (Esolen, 2020), akinek a politikai programja a paleokonzervatívokéhoz állt a legközelebb (Kolozi, 2017, 190-197. о.).

De mi az amerikai konzervativizmus és paleokonzervativizmus közti küiönbség? A kérdésre nagyon röviden térek csak ki, hiszen magyarul 
is több monográfia foglalkozik vele (lásd pl.: Egedy, 2014; Békés, 2008). Az alapítók szelleme miatt a nehézség az, hogy „konzervatívnak és tradicionalistának lenni Amerikában önellentmondás, mivel az amerikai [Edmund] Burke örökké John Locke liberalizmusát konzerválja" (Woodward, 1982. 20. o.). Az amerikai konzervativizmus inkább a gaz dasági szempontokat hangsúlyozza, a központi fogalma a szabadság, továbbá a korlátozott állam híve. Ezzel együtt számos irányzata léte zik az amerikai jobboldalon (tradicionalisták, libertáriusok, klasszikus liberálisok, neokonzervatívok, paleokonzervatívok stb.). Az azokat a gyakorlati politikában egyesítő és győzelemre vivő Reagan-koalíciót követően, azaz a kilencvenes évektől a Republikánus Párt establish menlje, amelyben meghatározóak voltak a neokonzervatívok, egyre inkább a neoliberális mainstreamhez közeledett, és az intervencionista, demokráciaterjesztő külpolitika rabjává vált. A paleokonzervatívok (a legismertebb alakjuk Patrick Buchanan) inkább izolacionista (de legalábbis nem intervencionista) külpolitikát szorgalmaznak, egyben a globális kapitalizmus erős kritikusai. Az amerikai nemzeti identitást féltik, és a protekcionista gazdaságpolitikát preferálják a korlátozott állam, a tagállami jogok és a kulturális konzervativizmus hangsúlyozása mellett. Elitellenesek és a „hétköznapi embert”, köztüik a munkásokat helyezik előtérbe. (Kolozi, 2017, 170. o.) A nemzeti identitás hangsúlyozása, a protekcionista gazdaságpolitika, a globális kapitalizmus bírálata és a szövetségi kormány korlátozása Trump politikájának is hangsúlyos része volt.

Vajon mit ért el Donald Trump a bel- és a külpolitikájában az azzal többé-kevésbé szimpatizáló konzervatívok szerint? Anthony Esolen professzor (a 2017-es „Out of Ashes - Rebuilding American Culture” címủ kötet szerzője) szerint: „A járvány kitörése előtt az amerikai gazdaság magabiztosan düibörgött. A 2016-os elnökválasztás óta a tőzsdepiacok 65 százalékkal (a Dow Jones szerint), 90 százalékkal (a Nasdaq szerint) vagy épp 100 százalékkal (a Standard and Poor's szerint) növekedtek. A hispánok és afroamerikaiak körében a legalacsonyabb volt a munkanélküliség azóta, hogy a kormányzat statisztikákat vezet erről. Az ipar elkezdett visszatérni oda, amit rozsdaövezetnek hívunk...” (Esolen, 2020). 


\section{Külïgyi Szemle}

Emellett Trump - helyesen - nekiment Kínának, és az adópoliti kájával „lazította a középosztálybeli és munkásosztálybeli amerikaia kon lévő pénzüigyi nyomást". Herbert Hoover óta ő volt a legkevésbé harcias elnök: nem indított háborút, és tető alá hozta az Ábrahámegyezményeket. Az izraeli nagykövetség Jeruzsálembe költöztetése pedig egy merész, számos korábbi elnök által is megígért, ám csak általa véghez is vitt lépés volt. Az illegális bevándorlás arányát a Barack Obama alattinak a tizedére csökkentette (Esolen, 2020; lásd még: Leimeiszter, 2020).

Chris Buskirk, az American Greatness alapító-főszerkesztője úgy látja, hogy Trump elnöki évei alatt a bérek nőttek, az illegális bevándorlók száma jelentősen csökkent, és ő volt ötven éve az első elnök, aki nem indított újabb küllföldi katonai akciót. Ám a „washingtoni elit ellenezte, hogy Trump az átlagos amerikaiak érdekeit tartotta szem előtt az elit érdekei helyett. De az átlagemberek ôt támogatták. És mind a három ügyben figyelemre méltó módon sikeres volt." (Buskirk, 2020).

Érdemes kitérni néhány megjegyzés erejéig a külpolitikára is. Trumpot egyrészt dicsérik, amiért nem bocsátkozott újabb háborúba, másrészt kritizálják, amiért „agresszív” külpolitikát folytatott. Trump kevésbé volt intervencionista, mint a hagyományos neokonzervatív elit, de a paleokonzervatívok izolacionizmusát sem tette teljes mér tékben magáévá. Elkerülte mind a Bush-kormányzatok demokrácia terjesztési próbálkozásait, mind az Obama-kormányzatok által agresszívan képviselt progresszív külpolitikai agendát, amely a liberális emberi jogi felfogás érvényesítését tartotta az egyik fő feladatának. Azonban Amerikára továbbra is a "hegyen épült városként” tekintett, hiszen az az általa képviselt nemzeti önkép szerves része. Donald Trump külpolitikája a Richard Nixon idején is képviselt pragmatikus realizmus irányzatához sorolható. „Agresszív” külpolitikája a (vélt) amerikai nemzeti érdek képviselete volt, amely a kölcsönösséget kér te számon a kereskedelmi egyezményeken, és csökkenteni igyekezett a Kínától való függést (ami állandó konfliktusokban manifesztálódott). Ez a felfogás a korábbi humanitárius és emberi jogi megközelítésú 
helyett tranzakcionalista - a „quid pro quo” [szívességet a szívessé gért] elve alapján működő, a multilaterális helyett a bilaterális megál lapodásokat előnyben részesítő - külpolitikával járt. Ez az unortodox külpolitika („újratervezés a világrendetlenségben”) összességében sikeresnek mondható, és a legtöbbször még az is jól sült el, ha az elnök - úgymond - „huszonegyre lapot húzott” (Kohán, 2020).

Az egyik első szerzô, aki a Trump-éveket tudományos igénnyel is pozitívan értékelte, minden bizonnyal John Yoo, a Kaliforniai Egyetem alkotmánytan-professzora, George W. Bush egykori tanácsadója, Clarence Thomas legfelsőbb bíró egyik jogásza volt. Ő sosem szavazott Trumpra, és eleinte osztotta a Trump-ellenesek félelmeit is, sőt számos lépésével ma sem ért egyet, ahogy a személyiségét sem kedveli. Ettől függetlenül úgy értékeli, hogy Trump az alkotmány és az elnöki hatalom védelmezőjévé vált a hivatalában töltött évek alatt. Amikor Trump Robert Mueller nyomozása ellen harcolt, az alkot mány által biztosított erős elnöki autonómiát és a hatalommegosztás elvét védte. A küilpolitika és a hadviselés terén is a végrehajtó hatalom hagyományos szerepét védelmezte. A legfelsőbb bíróságra pedig olyan tagokat nevezett ki, akik az alkotmány eredeti értelmezéséhez való visszatérést segítették. Mindemellett Trump a politikát felforgató személyiségével Yoo szerint is jót tett a közéletnek: például megrengette az alkotmányt egyre inkább önkényesen és kiterjesztőleg értelmezô elitek helyzetét is (Yoo. 2020).

\section{A 2020 -as választás és a megosztottság}

Általános az a vélekedés, hogy ha nincs a koronavírus-járvány és az erőszakos demonstrációsorozat, akkor Trump ma is a Fehér Házban lakna.

Úgy tűnik, hogy az amerikai „kisebbségek” jelentős része sem érzi Trumpot megosztónak: őrá szavazott a feketék 12, a hispánok 32, az ázsiai származásúaknak pedig 32 százaléka. A fiatal feketék és hispánok 30-35 százaléka támogatta ôt, míg az idősebbek sokkal kisebb arányban, azaz a kisebbségi fiatalok között sokkal több a republikánus és 


\section{Külïgyi Szemle}

a trumpista. A határ mentén fekvő texasi Zapata megyében, ahol 95 százalékban hispánok laknak, Trump 2020-ban is 52,5 százalékot kapott, míg négy éve csupán 33-at. De még a melegek egyharmada is Trumpra szavazott. A diplomások sem kizárólag Biden-szavazók

- távolról sem: az 55 százaléknyi felsőfokú végzettséggel rendelkező Biden-pártival 42 százaléknyi Trump-párti áll szemben. A diploma nélküliek körében mindkét jelölt támogatottsága 49 százalék volt (The New York Times, 2020).

Mindebből úgy tűnik, hogy a megosztottságot nem Trump okozta. Anthony Esolen szerint az amerikai társadalom már régóta megosztott, és az embereket nem lehet egyesíteni. Mint írta: „nem Trump és támogatói azok, akik szobrokat döntenek, templomokat rongálnak meg és épületeket gyújtanak fel" (Esolen, 2020), s való igaz, hogy a megosztó identitáspolitika és a woke left (szélsőbal) egyre meghatározóbb szerepet tölt be az amerikai baloldalon, amely a kisebbségek koalíciójából kívánna többséget építeni. Azonban lehet, hogy egyre több kisebbségi fogja megunni ezt, és inkább amerikaiként szeretne kisebbségi lenni - a megosztottság nélküli amerikaiságot pedig a jobboldalon találja majd meg.

A Demokrata Párt rég kimozdult a neoliberális balközépről, és balra tolódott; Trumppal a Republikánus Párt is eltért a neoliberális jobbközépről, és jobbra tolódott. A 2020-as elnökválasztásokon pedig rekordmagasságú volt a részvétel. A polarizáció mobilizál.

\section{A Trump-évek lehetséges örökségei}

A prosperálást hozó belpolitika, a békésebb és eredményes külpoliti ka, valamint az állandó önostorozással felhagyó, egészségesen patrió ta retorika bizonyosan sokat javított az amerikai társadalmon. A kon zervatív bírók kinevezése pedig a legfontosabb védvonalat alkothatja a következő évek demokrata politikájával szemben.

Alvino-Mario Fantini, a The European Conservative amerikai származású főszerkesztője szerint Trump mást is csinált: felrázta az amerikai közéletet. 
„Trumpnak sikerült elérnie valamit, amit kevesen vártak - újjjáé lesztette az amerikai politikai életet. Szinte senki nincs, akinek ne lenne véleménye az elnökről és kormányáról, akinek ne lenné nek határozott érzései egyik vagy másik irányban. Akár szereti, akár utálja valaki Donald Trumpot, azt nehéz volna tagadni, hogy véget vetett annak a veszélyes érdektelenségnek és apátiának, amely már hosszú ideje meghatározta az átlagos amerikai sza vazók viselkedését. Ez persze csak egyvalami, amivel az elnök kihívás elé állította a közéletet. Emellett szerencsére sok területen megzavarta a dolgok eddigi menetét. Akár az Egyesült Államokról, akár a nemzetek közösségéról beszélünk, Trump elutasítot ta a konvencionalizmust, a mai politikai elitek konszenzus által meghatározott és precedensekre alapozott, bevett politikáját. Ehelyett a saját útját járta." (Maráczi és Szilvay, 2020)

Tegyüik hozzá: nemcsak az egész amerikai politikai életet rázta fel (vagy ha tetszik: rázta meg) Donald Trump, hanem a szúkebb politikai közegét, a jobboldalt és a Republikánus Pártot is. Rod Dreher, a The American Conservative szerzője nagyon nem kedvelte Trump személyiségét, és üdvözölte a vereségét, ám a régi republikánus vonalhoz történő visszatérést sem szeretné: „van valami, amit kétségtelenül megköszönhetünk Trumpnak: hogy végleg lezárta annak lehetőségét, hogy a Republikánus Párt visszatérjen a zombie-reaganizmushoz" (Dreher, 2020). Ez pedig azt jelenti, hogy Trump esetleg a Republikánus Pártot az örök vereségtől mentette meg. Egyúttal pedig egy hagyományosabb konzervativizmushoz is közelebb vitte.

Gladden Pappin dallasi politológiaprofesszor három irányzatot tart valószínúnek a 2020 utáni, ,posztliberális” jobboldalon: a Bushféle neoliberális Never Trumpereket, a Trump-féle nemzeti konzervatívokat, valamint azokat, akik Trump elnökségét egy új.jobboldal létre hozására igyekeztek felhasználni (Pappin, 2020). Szerinte az amerikai jobboldal „tanulhatna az európai jobboldaltól, és nem tartana annyira a beavatkozó-védelmezó államtól”. Az ő ,integrista” elképzelése pedig „korporatív módon reintegrálná az államot, a társadalmat és a gazdaságot: egységes egészként kezelné azt” (Pappin, 2021). 


\section{Külïgyi Szemle}

Úgy látszik tehát, hogy a klasszikus amerikai szabadpiaci jobbol daliságtól eddig teljesen idegen irányzatok is létjogosultságot nyerhet nek Trump után.

\section{Mérleg}

Donald Trump elnöksége tehát rövid távon a belpolitikában gazdasági fellendülést, a külpolitikában pedig békésebb időket és gazdasági szabadságharcot hozott. Szokatlan lépései többsége jól „sült el”. Hoszszabb távon az általa kinevezett bírák és a legfelsőbb bíróság konzervatív többsége a konzervativizmus védőbástyái lehetnek.

Az elnöksége alatt Amerika megosztottsága még jobban felszínre került ugyan, de ezt a megosztottságot nem ő hozta létre. Ha ugyanis a republikánusok kizárólag arra figyelnének, hogy ne fokozzák azt, akkor be kellene hódolniuk a baloldalnak (vagy a saját oldalukon egyesíteniük az amerikai nemzetet).

Európai konzervatív és amerikai republikánus szempontból azonban a legfontosabb az, hogy Trump véget vetett az amerikai jobboldal paralizisének, és megmutatta, hogy némi bátorsággal és eltökéltséggel lehetséges másmilyen politikát folytatni, mint addig, és a politika egyes, addig áthághatatlannak hitt szabályai nyugodtan áthághatóak. Azaz Trump megszüntetett egy pszichológiai gátat, amely miatt a republikánusok folyamatosan megadták magukat a progresszió újabb és újabb ötletének.

A Trump-évek és a mostani útkeresés után az amerikai jobboldal talán jobban hasonlíthat majd a kontinentális jobboldalhoz, már ami a gondolkodása alapjait illeti; valamint bátrabb és magabiztosabb lehet, így nem fogja eleve veszni látni azokat az ügyeket, amelyeket képviselnie kellene. Donald Trump felrázta az amerikai jobboldali politikát, és megmutatta, hogy lehetséges nem önfeladó, hanem markánsan konzervatív politikát csinálni. Ez lehet az öröksége legmaradandóbb tanulsága. 


\section{Irodalomjegyzék}

Anton, Michael (2016). The Flight 93 Election. Claremont Review of Books. A letöltés ideje: 2016. szeptember 5. https://claremontreviewofbooks. com/digital/the-flight-93-election/.

Bacevich, Andrew J. (2020). The Age of Illusions. How America Squandered Its Cold War Victory. New York, NY: Metropolitan Books.

Békés Márton (2008). Amerikai neokonzervativizmus. Egy kisikloıt ellenforradalom. Budapest: Századvég.

Buskirk, Chris (2020). Trump minden tekintetben sikeres elnök. Mandiner. A letöltés ideje: 2020. október 30. https://mandiner.hu/cikk/20201030_ trump_minden_tekintetben_sikeres_elnok.

Chait, Jonathan (2020). How Michael Anton's 'Flight 93 Election' Essay Defined the Trump Era? New York Magazine's Intelligencer. A letöltés ideje: 2020. december 11. https:/nvmag.com/intelligencer/article/ michael-antons-flight-93-election-trump-coup.html.

Documen/Cloud (2012). Republican National Committee's Growth and Opportunity Project Report. A letöltés ideje: 2021. április 26. http:// www.documentcloud.org/documents/623664-republican-nationalcommittees-growth-and.html.

Dreher, Rod (2020). A személyiség végzet - Trump örökségéról. Mandiner. A letöltés ideje: 2020. október 27. https://mandiner.hu/cikk/20201027. rod dreher donald trump.

Egedy Gergely (2014). Konzervalív gondolkodás és politika az Egyesüll Államokban. Budapest: Századvég.

Esolen, Anthony (2020). Trump sikeres, a baloldal gyülölködik. Mandiner. A letöltés ideje: 2020. október 26. https://mandiner.hu/cikk/20201026 trump_sikeres_a baloldal gyulolkodik.

Friedersdorf, Conor (2016). An Attack on Founding Principles at the Clare mont Institute. The Allantic. A letöltés ideje: 2016. szeptember 9. https:// www.theatlantic.com/politics/archive/2016/09/an-attack-on-foundingprinciples-at-the-claremont-institute/499094/.

Kohán Mátyás (2020). Újratervezés a világrendetlenségben - ez volt Trump külpolitikája. Mandiner, 2(44).

Kolozi, Peter (2017). Conservatives Against Capilalism: From the Industrial Revolution to Globalization. New York, NY: Columbia University Press, 190-197. o. 


\section{Külïgyi Szemle}

Leimeiszter Barnabás (2020). Naggyá tette Trump Amerikát? Mandiner, 2(44).

Mansfield, Harvey C. (1998). Machiavellis Virlue. Chicago, IL: University of Chicago Press.

Maráczi Tamás és Szilvay Gergely (2020). Mi Trump mérlege? Mandiner, 2(44). 39-41. o.

Murray, Charles (2012). Coming Aparl: The Slate of While America, 1960 2010. Washington, DC: American Enterprise Institute, 2012.

Pappin, Gladden (2020). From Conservatism to Postliberalism: The Right After 2020. American Affairs, 4(3). https:/americanaffairsjournal. org $/ 2020 / 08 /$ rom-conservatism-to-postliberalism-the-rightafter-2020/?

Pappin, Gladden (2021). A magyar családpolitika minta lehet Amerikában is - Gladden J. Pappin a Mandinernek. Mandiner. A letöltés ideje: 2021. január 30. https://mandiner.hu/cikk/20210130_gladden_j_pappin interju.

Stumpf Anna (2017). Középfölde visszavág - Donald Trump elnökségének körvonalai. Kommentár, (2). 41-50.

Szilvay Gergely (2016). Index, Trump és a liberálisok rácsodálkozása az új valóságra. Mandiner. A letöltés ideje: 2016. december 9. https:// mandiner.hu/cikk/20161209_szilvay gergely_index_trump_es_a liberalisok racsodalkozasa az uj_valosagra.

The Lincoln Project (é. n.). https:/lincolnproject.us.

The New York Times (2020). National Exit Polls: How Different Groups Voted. A letöltés ideje: 2020. november 3. https:/www.nytimes.com/ interactive/2020/11/03/us/elections/exit-polls-president.html?

Trump, Donald J. (2017). Great Again. Újra naggyá lesszük Amerikát. Budapest: Európa Könyvkiadó.

Tóth Gergely (2016). Mémek, nácik és Trump: az amerikai szélsőjobb diadala. Index. A letöltés ideje: 2016. december 8. https:/index.hu/kulfold/usa/ feher_haz/2016/12/08/alt-right_mozgalom_amerikai_szelsojobboldal donald trump etnikai_allam/?

Wilhelm, Heather (2016). Cheer Up, Conservatives: We're Not Stuck on Flight 93. National Review. A letöltés ideje: 2016. október 9. https://www. national review.com/2016/09/flight-93-election-claremont-trumppiece-apocalyptic-rhetoric-overblown/. 
Woodward, C. Vann (1982). The Burden of Southern History. Baton Rouge, LA: LSU Press.

Yoo, John (2020). Defender in Chief: Donald Trump's Fight for Presidential Power. New York, NY: All Points Books. 